\title{
Subcutaneous immunotherapy with birch pollen extract for patients with pollen-food allergy syndrome
}

\author{
Hamada Masaaki ${ }^{1}$, Tanaka Ichiro ${ }^{2}$, and Kagawa Masakazu² \\ ${ }^{1}$ Yao Municipal Hospital \\ ${ }^{2}$ Yao Municipal Hospital
}

November 23, 2020

\section{Hosted file}

Main_document.pdf available at https://authorea.com/users/377994/articles/494587subcutaneous-immunotherapy-with-birch-pollen-extract-for-patients-with-pollen-foodallergy-syndrome

\section{Hosted file}

Table.xls available at https://authorea.com/users/377994/articles/494587-subcutaneousimmunotherapy-with-birch-pollen-extract-for-patients-with-pollen-food-allergy-syndrome

\section{Hosted file}

Figure.ppt available at https://authorea.com/users/377994/articles/494587-subcutaneousimmunotherapy-with-birch-pollen-extract-for-patients-with-pollen-food-allergy-syndrome 